\title{
Effects of top-soil drying on saltceder photosynthesis and stomatal conductance
}

\author{
MOHAMED MOUNSIF, CHANGGUI WAN, AND RONALD E. SOSEBEE
}

Authors are Professor, Department of Ecology and Range Science, National School of Agriculture, Meknes, Morocco Research Associate and Professor, Department of Range, Wildlife, and Fisheries Management, Texas Tech University, Lubbock, Texas 79409. At the time $r_{j}$ the research, the senior author was a Research Assistant, Department of Range, Wildlife, and Fisheries Management, Texas Tech University.

\begin{abstract}
Phreatophytes are trees and shrubs with deep roots tapping the water tables. As such they are presumed to be able to tolerate a water deficit in the top soil. Growth of some phreatophytes is decoupled from environmental factors such as incident precipitation. This study examined the effects of surface soil drying on gas exchange and stomatal conductance of a riparian phreatophyte Tamarix gallica $\mathbf{L}$. (saltcedar) during 2 consecutive growing seasons in which summer precipitation varied substantially. Daily average gas exchange (A) was $13.5 \mu \mathrm{mol} \mathrm{m}^{-2} \mathrm{sec}^{-1}$ in June and $13.4 \mu \mathrm{mol} \mathrm{m}^{-2} \mathrm{sec}^{-1}$ in September, 1991 when surface soil was wet as compared to the same periods of 1990 in which very little rain occurred (6.44 and $8.08 \mu \mathrm{mol} \mathrm{m}^{-2} \mathrm{sec}^{-1}$, respectively, $\left.\mathrm{P}<0.0001\right)$. Stomatal conductance (g) or maximal conductance showed a similar trend of photosynthesis. Both average gas exchange and stomatal conductance were correlated with water content in the upper portion of the soil $(r=0.83$ to 0.88 for $A, P<0.05$ and $r=$ 0.65 to 0.70 for $\mathrm{g}, \mathrm{P}<0.05$ ) in 1990 (a dry year). The variations in gas exchange or stomatac conductance of saltcedar were mainly caused by water availability in the upper soil layers, not by depth to the water table (0.65 vs $2.74 \mathrm{~m})$. The responses of gas exchange and stomatal conductance to surface soil drying in the phreatophyte saltcedar were similar to that of several crop species [lupin (Lupinus cosentinii Guss. cv. Eregulla), wheat (Triticum aestivum L. cv. Cadensa) and sunflower (Helianthus annuus L.)]. Our data suggest that upon soil re-wetting, when water availability to shallow lateral roots increased, the entire root system of saltcedar was actively involved in water uptake, leading to higher stomatal conductance and photosynthesis.
\end{abstract}

Key Words: phreatophyte, water relations, gas exchange, drought tolerance, Tamarix gallica $\mathrm{L}$.

Phreatophytes are woody or herbaceous plants that have roots that extend to the ground water table. There is much variability within this group in term of response to drought and relative use of water from deep vs. shallow soil horizons. According to Anderson (1982), the phreatophyte saltcedar (Tamarix spp.) typically derives its water supply from the water table and is able to tolerate drought. Busch et al. (1992), however, reported that facultative Tamarix ramosissima Ledeb. is capable of extracting

Contribution from the College of Agricultural Sciences and Natural Resources, Texas Tech University. The authors thank 2 anonymous reviewers for their comments on an earlier version of this manuscript.

Manuscript accepted 19 Mar. 01.

\section{Resumen}

Las freófitas sorı árboles y arbustos con raíces profundas que utilizan los mancos freáticos, se asume que ellas son capaces de tolerar el déficit de agua en al superficie del suelo. El crecimiento de algunas freófitas esta desacoplado de algunos factores ambientales, como la lluvia incidental. Este estudio examino los efectos del secado de la superficie del suelo en el intercambio gaseoso y la conductancia estomatal de la freófita ribereña Tamarix gallica L. (saltcedar). El estudio se condujo durante 2 estaciones de crecimiento consecutivas en las cuales la precipitación en verano varió substancialmente. El intercambio gaseoso diario promedio (A) fue de $13.5 \mathrm{Fmol} \mathrm{m}^{-2} \mathrm{sec}^{-1}$ en Junio y de $13.4 \mathrm{Fmol} \mathrm{m}-2 \mathrm{sec}-1$ en Septiembre de 1991, cuando la superficie del suelo estaba húmeda comparada con los mismos periodos de 1990 en los cuales ocurrió muy poca lluvia $\left(6.44\right.$ and $8.08 \mathrm{Fmol} \mathrm{m}^{-2} \mathrm{sec}^{-1}$, respectivamente, $P<0.0001)$. La conductancia estomatal (g) 0 conductancia máxima mostro una tendencia similar a la fotosíntesis. En 1990 (año seco), el intercambio gaseosos promedio y la conductancia estomatal estuvieron correlacionados con el contenido de agua de la porción superior del suelo $(r=0.83$ to 0.88 for $\mathrm{A}, \mathrm{P}<0.05$ and $\mathrm{r}=0.65$ to 0.70 for $\mathrm{g}, \mathrm{P}<\mathbf{0 . 0 5}$ ). Las variaciones en el intercambio gaseosos o la conductancia estomatal del "Saltcedar" fueron causadas principalmente por la disponibilidad de agua en las capas superiores del suelo, no por la profundidad del agua freática $(0.65 \mathrm{vs} 2.74 \mathrm{~m})$. Las respuestas del intercambio gaseosos y la conductancia estomatal del "Saltcedar" al secado de la superficie del suelo fueron similares a las de varias especies cultivadas [lupin (Lupinus cosentinii Guss. cv. Eregulla), trigo (Triticum aestivum L. cv. Cadensa) y girasol (Helianthus annuus L.)]. Nuestros datos sugieren que en base al rehumedecimiento del suelo, cuando la disponibilidad de agua para las raíces laterales superficiales incrementa, el sistema radical completo del "Saltcedar" estuvo activamente involucrado en la absorción de agua, conduciendo a una mayor conductancia estomatal y fotosíntesis.

water from the unsaturated soil layers as well, which confer a significant competitive advantage over the native obligate phreatophytes Populus spp. and Salix spp. that derive water solely from the water table.

Despite their ability to extract water from the unsaturated shallow soil, water relations of phreatophytes are mainly affected by the depth to water tables (Van Hylckama 1963, Stromberg et al. 1992). Phreatophytes can reach a high level of productivity because growth is decoupled from the normal limiting factor of precipitation (Wilkinson 1966, Nilsen et al. 1981). More recently, Donovan and Ehleringer (1994) showed that some desert shrubs 
do not respond to rainfall during the growing season. Devitt et al. (1997a) also concluded that it is doubtful that Tamarix would effectively utilize water from most summer rainfall events under hot, dry conditions. Because Tamarix can extract water from the unsaturated zone, plant water relations and photosynthesis of Tamarix may be affected by water deficit in the top soil. There is relatively little information, however, on the impact of surface soil drying on physiological responses of Tamarix. We evaluated the effects of surface soil drying on water relations and photosynthesis of the phreatophyte $T$. gallica L. growing in a riparian ecosystem in west Texas.

\section{Materials and Methods}

This study was conducted in Terry County, Texas $\left(102^{\circ} 16^{\prime} \mathrm{W}\right.$ and $\left.33^{\circ} 11^{\prime} \mathrm{N}\right)$ in the southern portion of the Great Plains. The site about $12 \mathrm{~km}$ east of Brownfield was selected adjacent to a saline pond where saltcedar exists in a dense stand. Climate of the area is semiarid with an average annual precipitation of $450 \mathrm{~mm}$. Monthly and annual precipitation vary considerably with May and June being the wettest months. Maximum potential evapotranspiration during May and June is about $16 \mathrm{~mm}^{\text {day }}{ }^{-1}$ (Texas Agricultural Experiment Station). The soil is an Amarillo fine sandy loam (fine-loamy, mixed, superactive, thermic aridic Paleustalf). The area supports a moderate stand of blue grama [Bouteloua gracilis (H.B.K.) Lag. ex Steud.], perennial three awns (Aristida spp.), and sideoats grama
[B. curtipendula (Michx.) Torr.]. Most of the area has been invaded by honey mesquite (Prosopis glandulosa Torr.) and saltcedar ( $T$. gallica).

Saltcedar trees of approximately equal size were selected at 3 locations within the stand (within interior, on the periphery and at the exterior). Measurements of photosynthesis (A) and stomatal conductance (g) were conducted 4 days a week biweekly June through September during 1990 and 1991, which represented a dry and a wet year, respectively (Fig 1). A Li-Cor 6200 portable photosynthetic system (LiCor Inc., Lincoln, Nebr.) was used to measure photosynthesis and stomatac conductance. Xylem water potential (XWP) was measured 3 times daily (predawn, midday and at 1600 hours) with a Scholander pressure bomb. Soil water content was measured gravimetrically for 4 soil depths $(0-15,15-30,30-45,45-60 \mathrm{~cm})$ on the first day of each sampling week $(n=4)$. Measurements of photosynthesis and stomatac conductance were also conducted on trees that grew adjacent to the pond and $60 \mathrm{~m}$ away from the pond in 1991 to study the impact of depth to water table ( $0.65 \mathrm{~m}$ vs $2.74 \mathrm{~m}$ ) on the ecophysiology of $T$. gallica.

Since the environmental conditions varied from day to day, measurements made on 1 day represent a block. Each block contained 3 trees, e.g. 1 tree from each location within the stand. Since the measurements were made on the same individual trees at each location over the sampling period, the data were analyzed by Analysis of Variance (ANOVA) using a Randomized Block Design (RBD) with a repeated measures analysis. The means

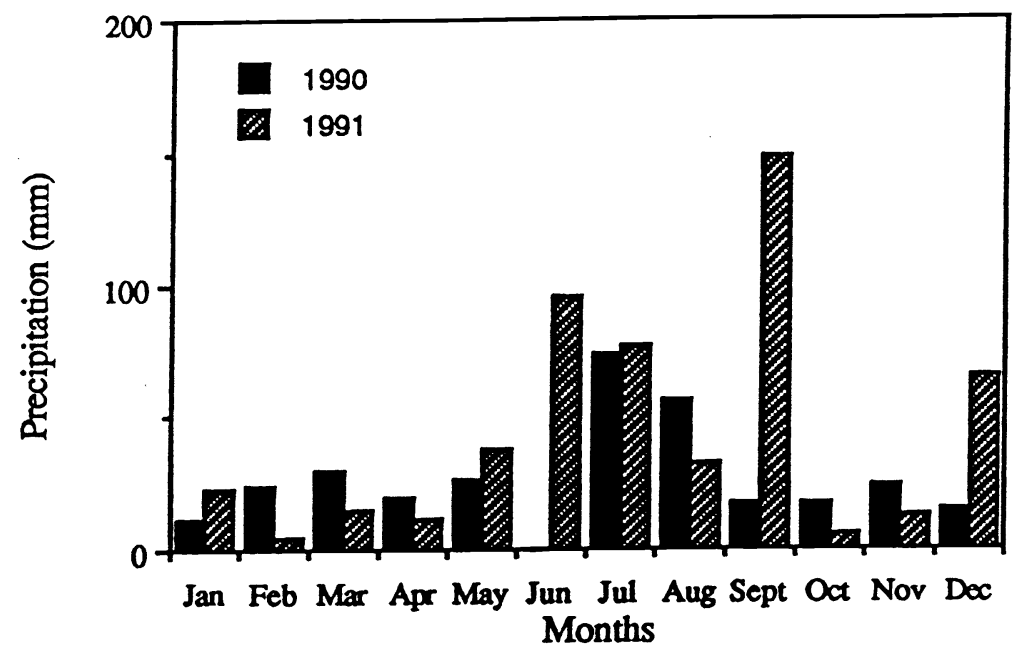

Fig. 1. Precipitation for Terry County, Texas in 1990 and 1991. The total precipitation was 316 $\mathrm{mm}$ for 1990 and $551 \mathrm{~mm}$ for 1991.

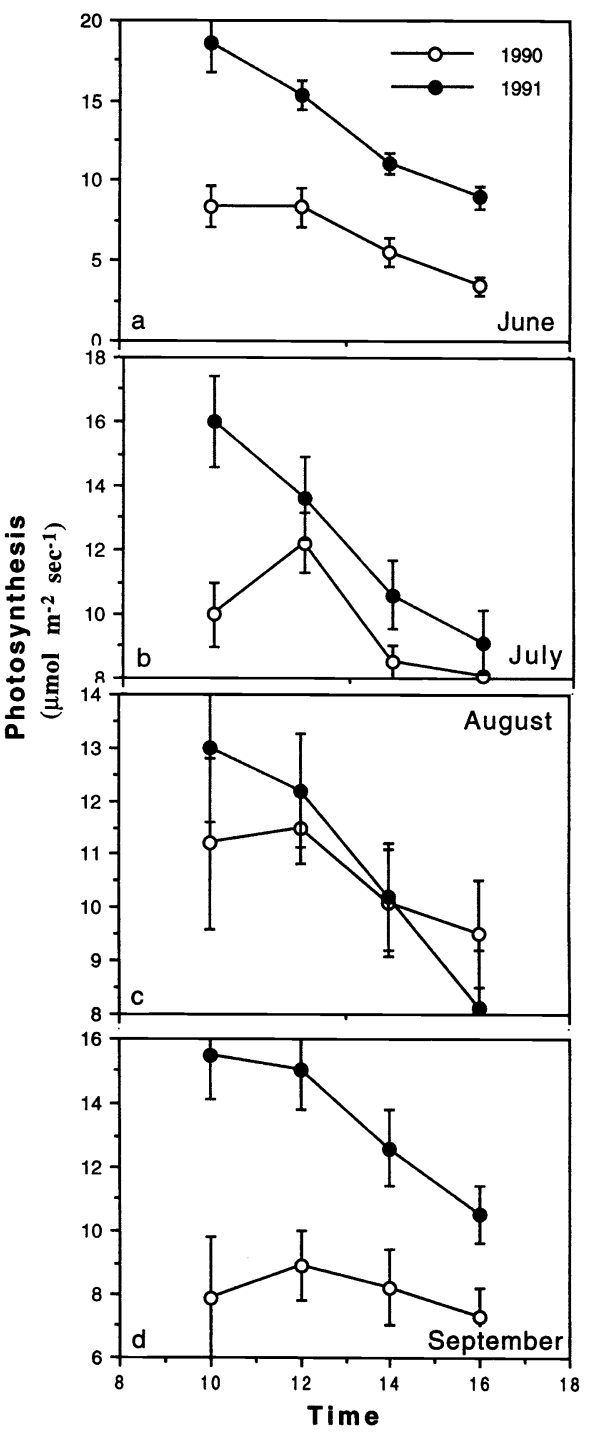

Fig. 2. Diurnal patterns of photosynthesis ( $\mu \mathrm{mol}$ $\left.\mathrm{m}^{-2} \mathrm{sec}^{-1}\right)$ of saltcedar trees growing in Terry County, Texas in 1990 and $1991(n=24)$. Vertical bars are standard error of mean. Photosynthesis was higher in $2 \mathrm{a}$ and $2 \mathrm{~d}$ in 1991 than in $1990(P<0.0001)$.

were separated using the protected Fisher's least significant difference (LSD) test.

\section{Results and Discussion}

The annual total precipitation was 316 $\mathrm{mm}$ for 1990 and $551 \mathrm{~mm}$ for 1991 ; the monthly precipitation is presented in Fig. 1. The diurnal patterns of photosynthesis and stomatal conductance from June through September are summarized in Fig. 2-3. There were no differences in the July precipitation between the 2 years, nor were there differences in photosynthesis 


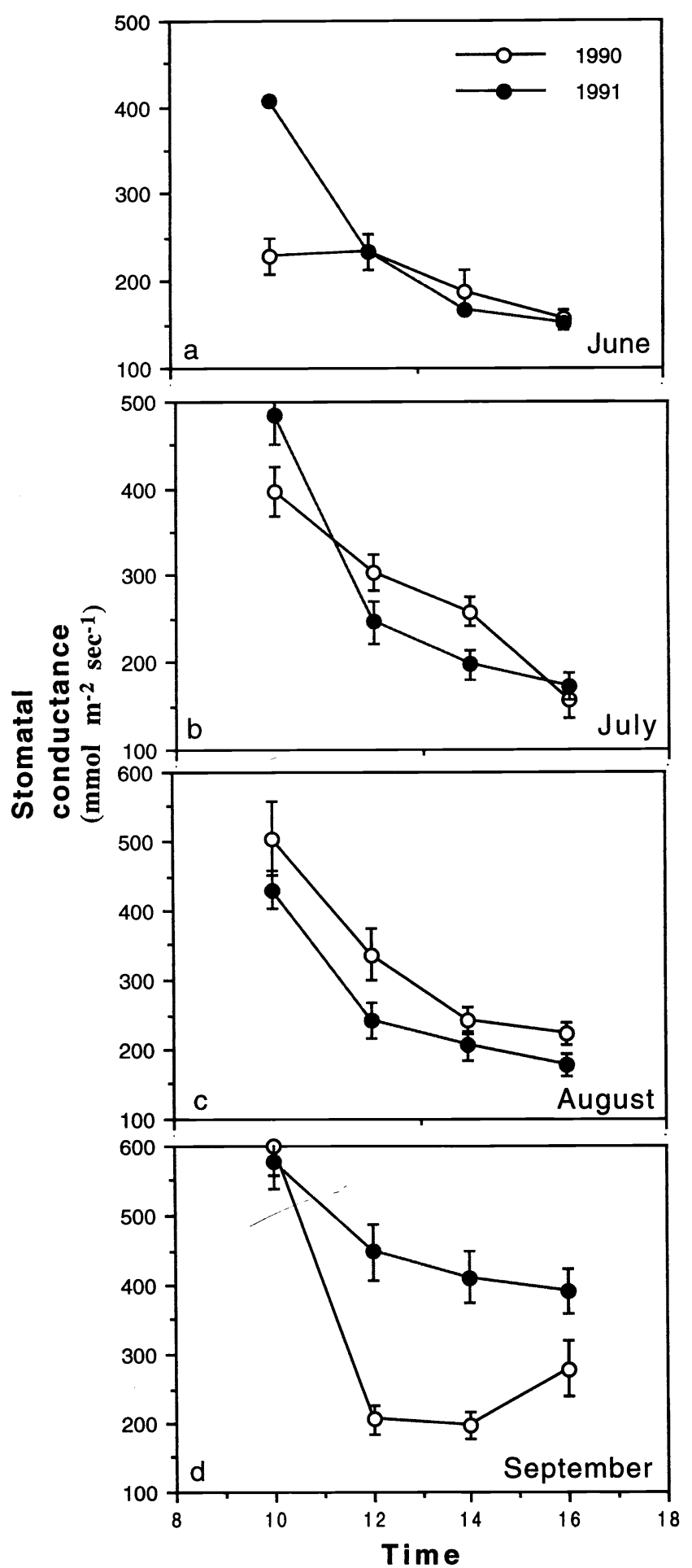

Fig. 3. Diurnal patterns of stomatal conductance $\left(\mathrm{mmol} \mathrm{m}^{-2} \mathrm{sec}^{-1}\right)$ of saltcedar trees growing in Terry County, Texas in 1990 and $1991(n=24)$. Vertical bars are standard error of mean. The maximum $\mathrm{g}$ in $3 \mathrm{a}$ and the average $\mathrm{g}$ in $3 \mathrm{~d}$ in 1991 was higher than in $1990(\mathrm{P}<0.01)$. The average $g$ in $3 \mathrm{c}$ was higher in 1990 than in $1991(\mathrm{P}<0.05)$, probably due to more precipitation in August, 1990 (Fig. 1).

and stomatal conductance (Fig. 1, 2b, 3b). Precipitation in June and September, 1991 was significantly higher than that in 1990 (Fig. 1). Likewise photosynthesis was 13.5 $\mu \mathrm{mol} \mathrm{m} \mathrm{mec}^{-1}$ in June and $13.4 \mu \mathrm{mol} \mathrm{m} \mathrm{m}^{-2}$ $\mathrm{sec}^{-1}$ in September $1991,109 \%$ and $66 \%$ higher, respectively, than during the same periods in 1990 ( $\mathrm{P}<0.0001$, Fig. 2a, 2d).
Stomatal conductance (or maximum g) exhibited patterns similar to that of photosynthesis (Fig. 3a, 3d). August precipitation in 1990 was higher than that in 1991, as was stomatal conductance in August, 1990 ( $\mathrm{P}<0.05$, Fig. 3c). The average leaf temperatures during the sampling periods ranged from $21.1^{\circ} \mathrm{C}( \pm 0.60, \mathrm{n}=24)$ in September to $40.3^{\circ} \mathrm{C}( \pm 0.17, \mathrm{n}=24)$ in June, and were not significantly different between years (data not shown).

In the dry year (1990), the average A was correlated $(\mathrm{P}<0.05)$ with water content of soil depths at $15-30 \mathrm{~cm}(\mathrm{r}=0.88, \mathrm{n}$ $=8), 30-45 \mathrm{~cm}(\mathrm{r}=0.83, \mathrm{n}=8)$ and $45-60$ $\mathrm{cm}(\mathrm{r}=0.87, \mathrm{n}=8)$, and the average stomatal conductance was correlated $(\mathrm{P}<0.05)$ with water content at $0-15 \mathrm{~cm}(\mathrm{r}=0.65, \mathrm{n}$ $=8)$ and $15-30 \mathrm{~cm}(\mathrm{r}=0.70, \mathrm{n}=8)$ soil depths. Correlations, however, were not significant in 1991. These results were consistent with Devitt et al. (1997b) who reported that in $T$. ramosissima growing at a groundwater depth of $3 \mathrm{~m}$, relative sap flow and stomatal conductance were a function of relative soil water in storage. Devitt et al. (1997b) also reported that leaf water potential of Tamarix declined to a minimum of $-3.5 \mathrm{MPa}$ during the drydown phase of their experiment, but plants responded within 24 hours to surface irrigation.

Water relations of phreatophytes are mostly affected by the depth to water table (Van Hylckama 1963, Stromberg et al. 1992). In wet years, the water table could rise due to high infiltration, which in turn affects water relations of saltcedar. In the riparian ecosystem where $T$. gallica grew, however, the deepest water table was only $2.74 \mathrm{~m}$ below soil surface which was well within the rooting depth of saltcedar (most trees were $>4 \mathrm{~m}$ tall). In 1991, the trees grown in proximity of the pond where depth to water table ranged from 0.60 to $0.65 \mathrm{~m}$ had similar photosynthesis and stomatal conductance when compared to trees $60 \mathrm{~m}$ away from the pond where depth to the water table was in the range of 1.64 to $2.74 \mathrm{~m}$ (data not shown). It appeared when saltcedar grew in soil with a relatively shallow groundwater source, variations in photosynthesis and stomatal conductance were mainly caused by water availability in the upper soil layers. This was different from the results of Van Hylckama (1963) who showed that saltcedar ( $T$. pentandra Pall.) trees grown in evapotranspirometers at a water table depth of $1.5 \mathrm{~m}$, transpired 29 and $56 \%$ more water than when the water table was 2.1 and $2.7 \mathrm{~m}$ deep. Our results agreed with Dugas et al. (1992) who reported that 

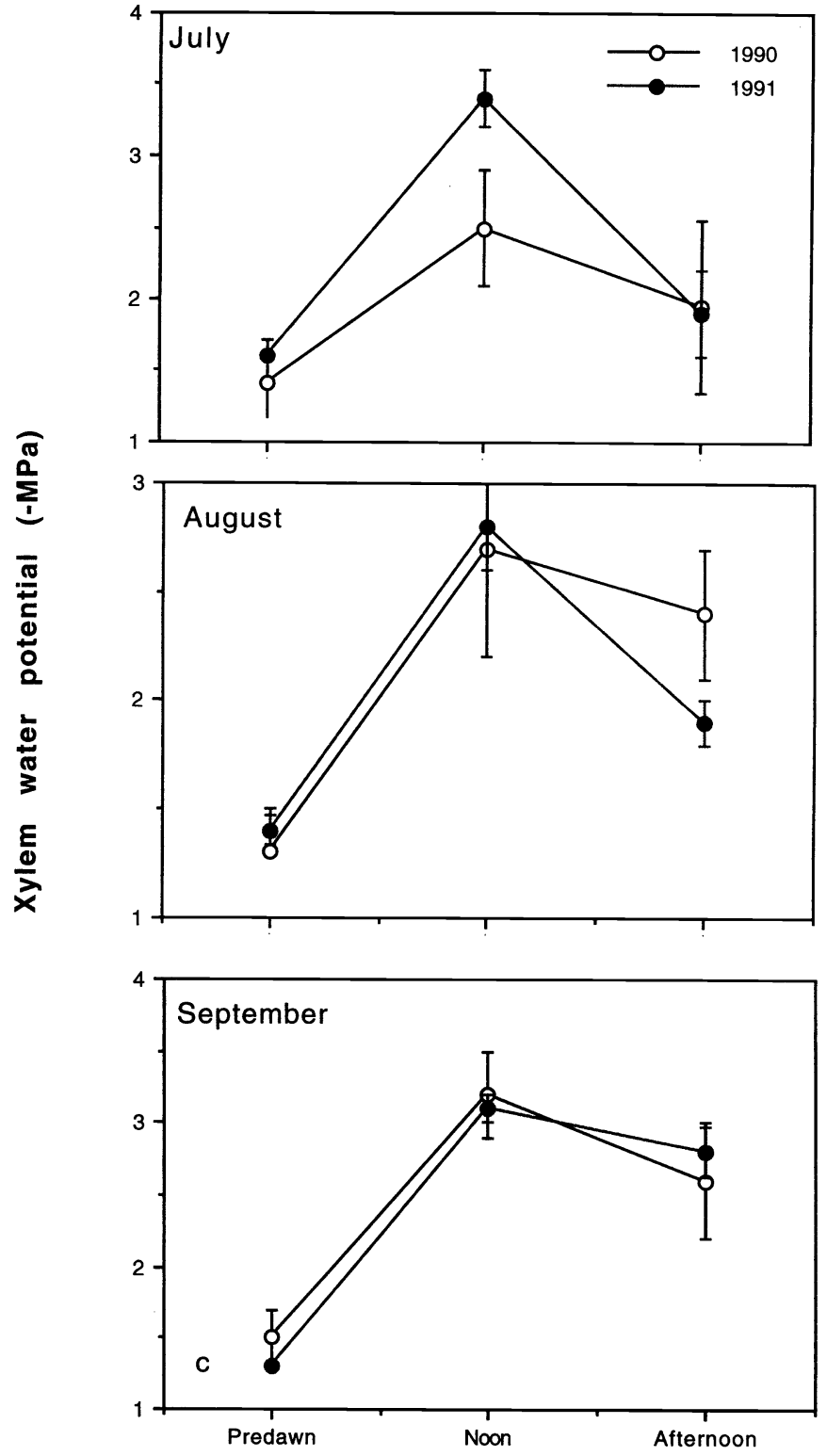

Fig. 4. Diurnal patterns of xylem water potential (XWP, -MPa) of saltcedar trees growing in Terry County, Texas in 1990 and $1991(n=12)$. Vertical bars are standard error of mean.

the facultative phreatophyte Prosopis exhibited $62 \%$ higher daily stem flow when surface soil was wet than when surface soil was dry.

Phreatophytes, by definition, are a group of deep-rooted trees and shrubs that obtain dependable water supply from the saturated water table. The predawn xylem water potential was similar between the 2 years (Fig. 4), indicating that drought in the 1990 growing season had limited effects on plant water status early in the morning due to absorption of the groundwater by the deep roots. There was a large variation in transpiration rate at the leaf level, therefore, no significant difference in transpiration was shown between the 2 years (data not presented). The roots with access to a water table could supply a large portion of the water requirements when surface soil was dry (Burgess et al. 2000) and transpiration rate was, to a large extent, regulated by leaf-air vapor pressure deficit. Our results, however, suggest that even in $T$. gallica trees growing in soil with a shallow water table, surface soil drying can substantially reduce photosynthesis and stomatal conductance.
Photosynthesis and leaf conductance exhibited similar diurnal patterns, and were both related to leaf-air vapor pressure deficit. For example, in 1990, the daily maximum leaf-air vapor pressure deficit was linearly correlated with daily average photosynthesis $(\mathrm{P}<0.0001, \mathrm{r}=$ $-0.84, \mathrm{n}=24)$, and with daily average stomatal conductance $(\mathrm{P}<0.0001, \mathrm{r}=$ $0.91, n=24)$ at the exterior of the stand. As leaf-air vapor pressure deficit increased in the afternoon, photosynthesis and stomatal conductance decreased (Fig. 2-3). Thus, photosynthesis and stomatal conductance were also susceptible to leaf-air vapor pressure deficit. As stomata closed in response to increased leaf-air vapor pressure deficit, water loss was curtailed and the plants were able to maintain a relatively stable xylem water potential (Fig. 4). Franco et al. (1994) observed that when predawn xylem water potential was $>-2 \mathrm{MPa}$ in Larrea tridentata (D.C.) Cov. the leaf-air vapor pressure deficit gradient had a large impact on photosynthesis and leaf conductance. In saltcedar, predawn xylem water potential was well above -2 MPa (Fig. 4), and photosynthesis and stomatal conductance were a function of leaf-air vapor pressure deficit which is consistent with observation reported by Franco et al. (1994).

Intercellular $\mathrm{CO}_{2}$ concentration $(\mathrm{Ci})$ was significantly lower during most of the growing season in 1991 than in 1990 (Fig. 5a-5c). Therefore, mesophyll conductance (A/Ci) was significantly higher in 1991 than in 1990. This suggested that photosynthesis was limited by the non-stomatal component, i.e., by the photosynthetic biochemistry. A low intercellular $\mathrm{CO}_{2}$ concentration indicated a higher mesophyll assimilation rate. Intercellular $\mathrm{CO}_{2}$ concentration often increases in dehydrated leaves (Lauer and Boyer 1992, Epron and Cornic 1993) because the photosynthetic apparatus is unable to fix $\mathrm{CO}_{2}$ fast enough to deplete intercellular $\mathrm{CO}_{2}$ concentration. A higher intercellular $\mathrm{CO}_{2}$ concentration in dehydrated leaves indicates that the demand for $\mathrm{CO}_{2}$ diminishes since metabolism is inhibited. During a dry growing season, even a phreatophyte like saltcedar had dehydrated, or wilted, leaves with low turgor as observed in this study (xylem water potential ranged from -2.5 to -3.5 $\mathrm{MPa}$ ), which resulted in reduced assimilation rates and high intercellular $\mathrm{CO}_{2}$ concentration.

In a controlled environment, Gallardo et al. (1994) reported that lupin $(L$. cosentinii Guss. cv. Eregulla) with a well-established root system can utilize localized supplies 


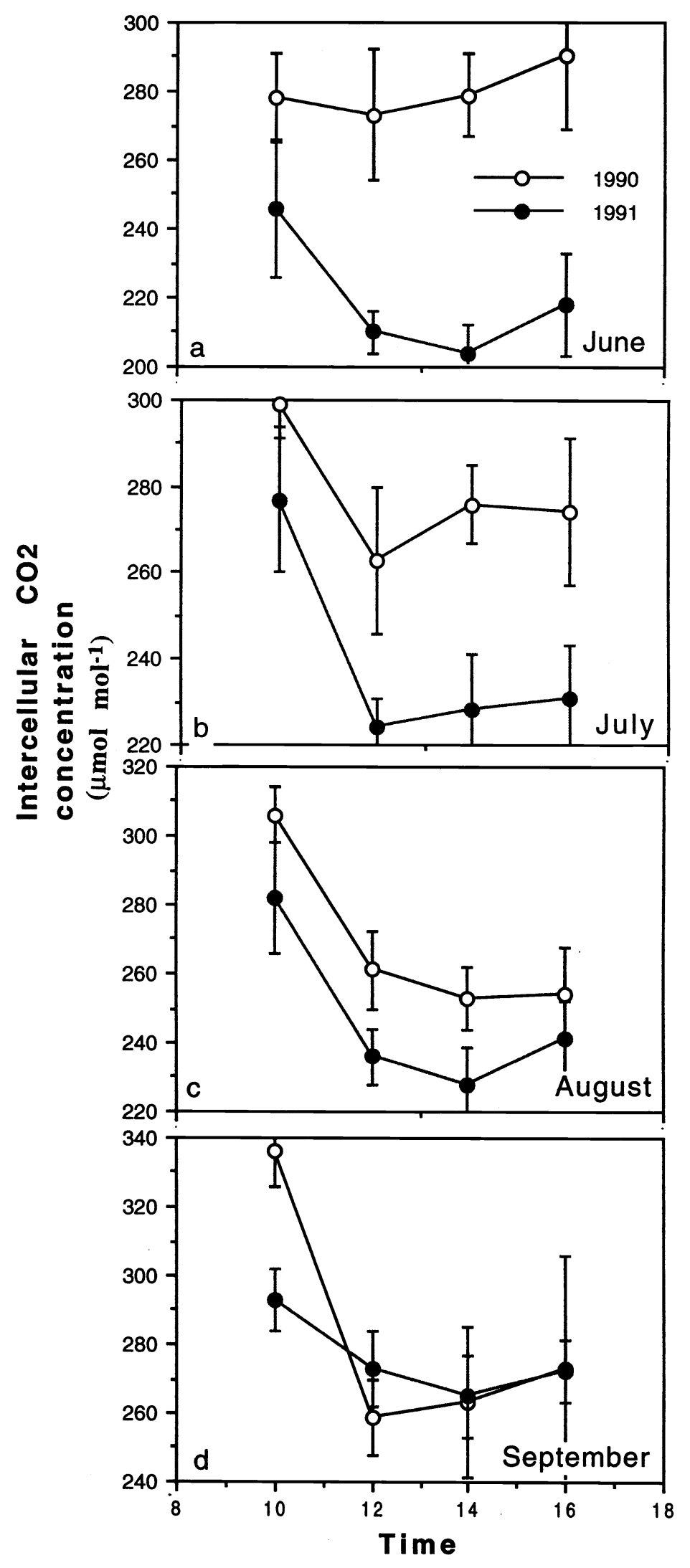

Fig. 5. Diurnal patterns of intercellular $\mathrm{CO}_{2}$ concentration $\left(\mu \mathrm{mol} \mathrm{CO}_{2} \mathrm{~mol}^{-1}\right)$ of saltcedar trees growing in Terry County, Texas in 1990 and $1991(n=24)$. Vertical bars are standard error of mean. Intercellular $\mathrm{CO}_{2}$ concentration was lower in 1991 than in $1990(\mathrm{P}<0.05)$ in $5 \mathrm{a}-5 \mathrm{c}$. of available soil water to maintain leaf gas exchange despite appreciable portion of the root system being in dry soil. They speculated that the increased water uptake by deep roots may have diluted any abscisic acid (ABA) produced by the roots in the dry soil. However, other studies (Zhang and Davies 1989, Henson et al. 1989, Ali et al. 1998) reported that partial soil drying reduced stomatal conductance and leaf growth due to root-borne chemical signals in the dry soil. Photosynthesis is closely related to the extent of leaf hydration (Kaiser 1982) which depends on water uptake and hydraulic conductance of the root system. Graham and Nobel (1999) showed that under field conditions the entire root system of Agave deserti (Engelm.) must be rewetted for maximal carbon gain to occur rapidly. In west Texas where potential evapotranspiration can reach as high as $16-18 \mathrm{~mm}$ per day during a drought period (Wan et al. 1998), water uptake by saltcedar from the deep water source was unlikely to be available in quantities large enough to completely relieve leaf water deficit as indicated by sharply reduced leaf conductance (Fig. 3) and leaf wilting. Burgess et al. (2000) showed that in the woody pheatophyte Banksia prionotes (Proteaceae) relative contribution of the taproot to total water uptake during a dry period was $80 \%$, which declined steadily to $45 \%$ with increased rainfall and increased availability of water to lateral roots. In the wet year (1991), when water availability to lateral roots increased, the entire root system of saltcedar was probably actively involved in water uptake, leading to rapid leaf hydration and higher photosynthesis.

As a phreatophyte, saltcedar plants have maximum root development in the capillary fringe above the water table and are able to tolerate drought (Anderson 1982, Cleverly et al. 1997). However, in this experiment gas exchange and stomatal conductance was shown to be quite susceptible to a summer drought. Since saltcedar is a deep-rooted plant, a summer drought may only represent a mild water stress as indicated by predawn xylem water potential. Yet, photosynthesis and leaf conductance declined in response to this mild water stress. Furthermore, the response of saltcedar to partial soil drying was not different from that of several relatively shallow-rooted crop species such as wheat, lupin and sunflower (Zhang and Davies 1989, Henson et al. 1989, Ali et al. 1998). This suggests that the dual root system makes saltcedar a highly opportunistic water user: it can effectively use soil water 
wherever it is available. When the surface soil is wetted by rainfall, water uptake from the upper soil profile contributes greatly to plant water consumption, while the plants depend mainly on the deep roots for water supply during a drought. The ability of saltcedars to closely regulate photosynthesis and leaf conductance during drought increases its survivability in arid and semiarid rangelands. The rapid response of saltcedar to summer rainfall enhances photosynthetic production and competitiveness against the obligate pheatophytes that depend only on groundwater source for growth.

\section{Literature Cited}

Ali, M., C. R. Jensen, and V. O. Mogensen. 1998. Early signals in field grown wheat in response to shallow soil drying. Aust. J. Plant Physiol. 25:871-882.

Anderson, J.E. 1982. Factors controlling transpiration and photosynthesis in Tamarix chininsis Lour. Ecol. 63:48-56.

Burgess, S. S. O., J. S. Pate, M. A. Adams, and T. E. Dawson. 2000. Seasonal water acquisition and redistribution in the Australian woody phreatophyte, Banksia prionotes. Ann. Bot. 85:215-224.

Busch, D. E., N. L. Ingraham, and S. D. Smith. 1992. Water uptake in woody riparian phreatophytes of the southwestern United States: a stable isotope study. Ecol. Appl. 2:450-459.

Cleverly, J. R., S. D. Smith, A. Sala, and D. A. Devitt. 1997. Invasive capacity of Tamarix ramosissima in a Mojave Desert floodplain: the role of drought. Oecologia 111:12-18.
Devitt, D. A., A. Sala, K. A. Mace, and S. D. Smith. 1997a. The effect of applied water on the water use of saltcedar in a desert riparian environment. J. Hydrology. 192:233-246.

Devitt, D. A., J. M. Piorkowski, S. D. Smith, J. R. Cleverly, and A. Sala. 1997b. Plant water relations of Tamarix ramosissima in response to the imposition and alleviation of soil moisture stress. J. Arid Environ. 36:527-540.

Donovan, L. A. and J. R. Ehleringer. 1994. Water stress and use of summer precipitation in a Great Basin shrub community. Funct. Ecol. 8:289-297.

Dugas, W. A., M. L. Heuer, and H. S. Mayeux. 1992. Diurnal measurements of honey mesquite transpiration using stem flow gauges. J. Range. Manage. 45:99-102.

Epron, D. and G. Cornic. 1993. The use of chlorophyll fluorescence to investigate the effects of dehydration on leaf photosynthesis. Curr. Top. Plant Physiol. 1:177-184.

Franco, A. C., A. G. Soyza, R. A. Virginia, J. F. Reynolds, and W. G. Whitford. 1994. Effect of plant size and water relations on gas exchange and growth of the desert shrub Larrea tridentata. Oecologia 97:171-178.

Gallardo, M., N. C.Turner, and C. Ludwig. 1994. Water relations, gas exchange and abscisic acid content of Lupinus cosentinii leaves in response to drying different proportions of the root systems. J. Exp. Bot. 45:909-918.

Graham, E. A. and P. S. Nobel. 1999. Root water uptake, leaf water storage and gas exchange of a desert succulent: Implications for root system redundancy. Ann. Bot. 84:213-223.

Henson, I. H., C. R. Jensen, and N. C. Turner. 1989. Leaf gas exchange and water relations of lupins and wheat. I. Shoot response to soil water deficit. Aust. J. Plant Physiol. 16:429-442.
Kaiser, W. M. 1982. Correlation between changes in photosynthetic activity and changes in total protoplast volume in leaf tissue from hygro-, meso- and xerophytes under osmotic stress. Planta 154:538-545.

Lauer, M. J. and J. S. Boyer. 1992. Internal $\mathrm{CO}_{2}$ measured directly in leaves: Abscisic acid and low leaf water potential cause opposing effects. Plant Physiol. 98:1310-1316.

Nilsen, E. T., P. W. Rundel, and M. R. Sharifi. 1981. Summer water relations of the desert phreatophyte Prosopis glandulosa in the Sonoran desert of southern California. Oecologia 50:271-276.

Smith, S. D., R. K. Monson, and J. E. Anderson. 1997. Physiological ecology of North American desert plants. Springer, Berlin.

Stromberg, J. C., J. A. Tress, S. D. Wilkins, and S. D. Clark. 1992. Response of velvet mesquite to groundwater decline. J. Arid Environ. 23:45-58.

Van Hylckama, T. E. A. 1963. Growth, development, and water use by saltcedar (Tamarix pentandra) under different conditions of weather and access to water. Int'l. Assoc. Sci. Hydrol. 62:75-86.

Wan C. G., R. E. Sosebee, and B. L. McMichael. 1998. Water relations and root growth of two populations of Gutierrezia sarothrae. Environ. Exp. Bot. 39:11-20.

Wilkinson, R. E. 1966. Seasonal development of anatomical structures of saltcedar foliage. Bot. Gaz. 127:231-234

Zhang, J. and W. J. Davies. 1989. Sequential response of whole plant water relations to prolonged soil drying and involvement of xylem sap ABA in the regulation of stomatal behavior of sunflower plants. New Phytol. 113:167-174. 